\title{
O PAJÉ E O CABOCLO: DE HOMEM A ENTIDADE*
}

Véronique Boyer

\begin{abstract}
Debaixo da obediência das três pessoas da Santíssima Trindade eu peço licença para comunicar-me com os espíritos dos sete Caboclos e das sete Caboclas, curadores e curadoras. Ó almas benditas dos caboclos e das caboclas, vós fôstes como eu e eu serei como vós. (Oração dos Sete Caboclos apud Câmara Cascudo 1951).
\end{abstract}

$\mathrm{N}$ a hora da possessão, mas também nas discussões informais entre integrantes dos cultos de possessão brasileiros urbanos, não é rara a referência a um personagem familiar: o caboclo. Durante as chamadas sessões de terreiro, cada médium representando um caboclo diferente escuta os pedidos dos consulentes relativos à saúde deficiente, situação familiar instável ou emprego precário. Em retorno, todos recebem consel hos de firmeza e perseverança, às vezes formulados em tom irônico, outras vezes enunciados com compaixão. Aqueles que, segundo um possuído, não comparecem com assiduidade ao terreiro, podem ser alvo de uma apóstrofe nem sempre agradável, assim como também poderiam sê-lo os novos clientes que, estranhando por não reconhecerem naquele médium o "caboclo" que costumam consultar, viessem a compartilhar esses pensamentos com os demais presentes.

De qualquer forma, a crítica só poderia ser velada. Um médium elabora, como faria um ator no palco, a sua própria interpretação do papel do caboclo, interpretação que não se confunde com nenhuma outra. Mas para convencer o público da presença do ser invisível, a composição deve incluir traços diferentes dos da própria personalidade do filho-de-santo quando "consciente". A dimensão de criatividade pessoal, associando estreitamente o ser humano e o espírito ${ }^{1}$ aos olhos dos conhecidos, permite instituir o caboclo na posição de companheiro do médium, o qual passa então a dirigir sua vida como se esse outro mandasse nele. A eficá- 
cia do caboclo, prova da competência do médium, é assim função de uma identidade afirmada na diferença.

Durante a primeira parte deste século, a elaboração cultural do caboclo enquanto categoria do mundo invisível parece ter-se apoiado em uma dinâmica análoga, incluindo-o simultaneamente nos registros da intimidade e da estranheza. Gostaria aqui de examinar o surgimento desse caboclo invisível, levantando a hipótese de que este se deu mediante um trabal ho simbólico árduo sobre a multiplicidade de sentidos da palavra caboclo (dentre os quais alguns são hoje obsoletos).

O caso de Belém, onde fiz pesquisa de campo, é particularmente interessante, pois lá os espíritos cabocl os fundem diversas categorias de entidades que permanecem separadas em outras regiões. N esta cidade, os pretos-velhos, as crianças e, de maneira mais complexa, os exus ${ }^{2}$ encarnam, cada um a seu modo, aspectos diferentes dos caboclos: quando jovem, adulto, idoso..., abrindo o leque de personagens singulares dos quais um médium pode apoderar-se para conquistar fama e prestígio. $O$ caboclo é assim a figura central dos cultos de possessão da região.

Para entender a importância da extensão do termo caboclo a qualquer ser invisível ${ }^{3}$, deve-se considerar o contexto amazônico em que se situa a capital paraense. Em uma região que concentra a mais alta porcentagem de populações indígenas, mas sobretudo onde os vestígios de práticas e crenças autóctones se encontram ainda vivos no meio rural, a palavra "caboclo" é associada, mais do que em outro lugar qualquer, a referências culturais intimamente ligadas à história das suas origens. A bandonando o sentido de índio ou de mestiço de índio e branco, caboclo, para a população atual da cidade, designa geralmente o habitante do meio rural qualquer que seja a sua origem, muitas vezes apresentando-o como crédulo e idiota. De fato, o uso do termo tem uma forte carga negativa. Denota a pouca consideração que se tem para com aquele que se qualifica dessa forma, quando não torna explícito o desejo de ofendêlo. A definição do caboclo enquanto ser invisível vem, então, na sociedade amazônica, junto com outra: o caboclo como interiorano.

A pergunta é, portanto, a seguinte: qual a relação existente entre o representante do interior, visto como grosseiro e atrasado, e o personagem poderoso e sábio que os médiuns incorporam? Como veio a constituir-se o caboclo invisível a partir desses traços de comportamento atribuídos ao interiorano e o que subsiste nele da idéia do caboclo-homem? Uma resposta radicalmente negativa é tentadora, mas seria a meu ver errônea por duas razões. A primeira remete ao plano simbólico. A construção do personagem do caboclo pelos médiuns integra quase sempre 
gestos e comportamentos associados pelas classes médias à falta de educação do povo: os "caboclos" xingam e bebem demais, todos recusam-se a ler e a aprender a contar as horas, alguns se vangloriam das travessuras que fizeram, enquanto outros, por princípio e para o prazer do público, estranham as coisas ligadas à "modernidade". A potência de que disporia a entidade vai junto aqui com uma rudeza e uma ignorância que parecem ser herdadas, entre outros, do estereótipo do homem caboclo. A marginalidade do caboclo-ser humano é de certa maneira reconduzida nessa "vulgaridade" que é parte integrante da composição do espírito pelos médiuns.

O segundo argumento é sociológico. Boa parte da população urbana é, sem dúvida nenhuma, originária do interior, e outra parte ainda tem parentes lá. N essa medida, a condição atual de citadino pode ser enunciada em relação ao deslocamento do meio rural. Certas pessoas afirmam que "foram caboclos" antes da chegada e adaptação ao meio urbano, enquanto outras mencionam que membros da sua família ainda o são. A relação com o interior, onde vivem por definição os caboclos, é tanto mais intensa quanto o fluxo das migrações, através dos laços familiares, Ihe dá consistência e a reativa com regularidade: o caboclo, diferente do habitante da cidade, não chega a ser radicalmente estranho.

\section{As primeiras menções dos cultos de caboclos}

As primeiras menções dos cultos de caboclos datam do início do século. Para Salvador, no livro do médico Nina Rodrigues (1862-1906), Os Africanos no Brasil, consta a expressão "candomblé de caboclo" (1977:221), sem que infelizmente essa modalidade de culto seja descrita com mais detalhes.

Quase na mesma época, ainda nessa cidade, M anuel Querino (18511923), com o objetivo de estabelecer uma lista das contribuições do africano à cultura brasileira, publica em 1919 um pequeno artigo sobre o "Candomblé de Caboclo". O autor nota, neste culto "bastante arraigado entre as classes inferiores desta capital" (1955:117), a designação de J esus Cristo como nome de "caboclo bom". A lém disso, faz uma descrição muito interessante do comportamento dos médiuns possuídos pelos caboclos, chamados também "santos", que lembra as possessões atuais: "Quem está com o santo corteja as pessoas presentes segurando-Ihes as mãos, dá dois saltos perpendiculares, abraça-as de um lado e do outro, faz-Ihes algumas determinações, dá-Ihes conselhos e retira-se" (Querino 
1955:118). De fato, o caráter de sociabilidade em torno da possessão, ao qual o autor do texto foi sensível, persiste ainda hoje nas sessões dos terreiros.

Por sua parte, em um livro editado pela primeira vez em 1934, Arthur Ramos transcreve um trecho de um jornal de Salvador, O Diário da Bahia, de 1929, ironizando sobre os médiuns possuídos por "espírito de caboclo endiabrado" (1951:123), antes de insistir sobre a novidade desses cultos: “Há uma modalidade de sincretismo religioso que só agora vem tomando grande incremento, o que prova que a sua aparição é relativamente recente. É o chamado 'candomblé de caboclo', na Bahia, ou 'linha de caboclo', no Rio de J aneiro" (1951:138).

Enfim, Edison Carneiro será um dos poucos pesquisadores a fornecer uma descrição detal hada desses cultos, apontando para as principais diferenças entre o candomblé dito "tradicional" e o candomblé "de caboclo". Segundo ele (1961:101-104), no candomblé de caboclo, além da introdução desses novos personagens ao lado dos orixás, o tempo da iniciação foi drasticamente reduzido, os tambores são batidos com a palma da mão, os filhos-de-santo são possuídos por vários "encantados" 4 e não se recolhem para mudar de roupa quando incorporados. À diferença do candomblé "tradicional", a representação dos personagens invisíveis aceitaria comportamentos associados à natureza humana, pois os encantados falam, bebem, fumam e apresentam-se ao público com a ajuda de um canto. Aliás, o transe, segundo o autor, não se restringe aos iniciados, atingindo qualquer pessoa da assistência. Por fim, procurando enfatizar o estilo diferente da dança nos candomblés de caboclos em relação à coreografia nos terreiros "tradicionais", Carneiro é levado a descrever a primeira como "animada, vivaz e decorativa, permitindo muito de iniciativa pessoal", e a segunda como "pesada, desgraciosa e monótona" (1961: $101)^{5}$.

No entanto, essas diferenças, que se organizam em torno da simplificação do aparelho ritual e iniciatório, não constituem critérios absolutos que permitam uma classificação rígida dos terreiros. Com efeito, o autor pôde "ver cantar e dançar para os encantados caboclos" nos candomblés do "Engenho Velho e do Gantois, duas casas onde a tradição kêto [yorubá, isto é, africana] exerce uma verdadeira tirania" (Carneiro 1961:62). A inovação, assim, parece ter ocorrido também nos mais antigos terreiros de Salvador.

Para Recife, que eu saiba, só temos como fonte de conhecimento o trabalho de René Ribeiro, publicado pela primeira vez em 1952. O autor, observando que nos centros mais ortodoxos os fiéis acreditam na coexis- 
tência dos orixás e dos espíritos de caboclos, comprova a asserção de Carneiro para Salvador. Ribeiro acrescenta que os membros dos terreiros não só crêem que os caboclos são "mais suscetíveis às manipulações mágicas que os deuses africanos", como atribuem al gumas das suas "complicações de vida [...], doenças e outros infortúnios", não à punição dos orixás, mas à "interferência indébita desses seres menores" (1978:131). Dessa forma, escreve ele, os médiuns pensam que partilham a sua existência “parte com orisha e parte com caboclo" (1978:131).

As informações são ainda mais tênues para Porto Alegre. Melville Herskovits (1966:201) assegura que lá não existem espíritos caboclos. $\mathrm{M}$ as, como diz Carneiro, os cultos da cidade, que os pesquisadores chamam de batuque, são designados pel os fiéis pelo termo "pará". Deve-se então notar, com Carneiro (1964:128), que "pará parece [um termo de origem] tupi e não africana"; e que se trata também do nome de um estado amazônico da União.

Para o Rio de J aneiro, informações são fornecidas por Yvonne M aggie, em uma tese defendida em 1988, onde, a partir de um levantamento cuidadoso dos autos de processos de 1890 e 1940, a autora analisa a contribuição da instituição jurídica tanto à constituição do campo religioso dos cultos de possessão quanto à definição das relações de poder entre eles. Dentre os elementos simbólicos introduzidos no sistema religioso, encontra-se o termo caboclo, muitas vezes associado ao de "protetor", para designar os seres invisíveis representados pelos médiuns, termo que vem no Rio a ter maior recorrência a partir dos anos 30. Arthur Ramos descreveu para o Rio uma possessão por um santo protetor, "velho antepassado da Costa da África", que lembra bastante aquela feita por Manuel Querino para Salvador: "Pai J oaquim aproxima-se. À sua passagem, todos se curvam e lhe pedem a bênção. Êle vai abraçando velhos conhecidos, como se tivesse chegado de longa viajem. Interroga pelo estado de saúde de cada um, dá conselhos, resolve dificuldades" (1956:129).

Paradoxalmente, pois o termo é comum ao falar dos homens da Amazônia, não há registro algum, antes do estudo de Seth e Ruth Leacock (1972), de espíritos caboclos para os cultos de possessão da região N orte. Quando os estudiosos evocam seres invisíveis, referem-se unicamente aos "encantados que descem sobre os pajés" (os especialistas religiosos locais) e às vezes a esses "deuses que nos vieram da África" (Andrade, 1963:29), isto é, aos orixás. No entanto a ausência de menção a espíritos protetores caboclos na literatura amazônica não significa, como veremos, que o caboclo não tenha ocupado um grande espaço nas preocupações locais. 


\section{Santos, orixás, caboclos negros, caboclos índios}

A aparição da figura dos caboclos leva a uma inflação de termos para designá-los. São chamados, escreve Carneiro (1964:129), “orixás ou vôduns, vocábulos nagô e jêje, respectivamente, encantados, caboclos, santos, guias ou anjos-da-guarda". Seu estatuto de intercessor Ihes vale, muitas vezes, serem estreitamente associados aos santos católicos. Dos testemunhos que Maggie analisou, há o depoimento de uma senhora idosa, afirmando em 1929 que um conhecido seu recebe "espíritos de caboclos" e que um deles se chama Santo Antônio, popular santo de devoção. Um processo análogo parece ter acontecido no que diz respeito à relação entre caboclos e orixás. Carneiro (1961:65-67) menciona, por exemplo, que, nos anos 30, tanto Ogum (divindade da guerra) ou Oxalá ("o maior dos santos", diz dele Arthur Ramos) quanto Xangô (orixá da mata) ou Oxóssi (orixá da caça) eram qualificados de caboclos, o que provocava, segundo o autor, bastante confusão com as divindades instaladas antes deles nos cultos de possessão. Ainda hoje subsistem certas ambigüidades. Assim, apesar do uso de palavras diferentes para os santos e os orixás, por um lado, e para os caboclos, por outro (os médiuns usam geralmente o termo "entidade" para os primeiros, enquanto reservam o termo "espírito" aos segundos), a divisão das águas nem sempre é respeitada e só o contexto da enunciação permite decidir sobre o sentido das palavras.

Porém, esse primeiro movimento, em que os caboclos parecem puxados "para cima" junto com os orixás e os santos, se faz acompanhar de outro, através do qual os primeiros vão progressivamente dissociar-se dos outros dois, para assumir uma posição mais próxima dos seres humanos, permitindo aos filhos-de-santo que os encarnam interpretar a relação instituída como "companheirismo" 6 . O retrato do caboclo desenhado pelos diversos estudos mostra a especificidade dessa figura, tanto nas atitudes que os possuídos devem adotar para ter credibilidade, quanto na posição que este ocupa no sistema religioso. Ao contrário dos orixás, esse personagem assume comportamentos humanos (bebe e fuma), não precisa da mediação da hierarquia sacerdotal (apresenta-se sozinho ao público e possui os não-iniciados) e estabelece uma relação íntima com os seres humanos ("corteja" e dá consel hos). "Seres menores" ou "espíritos", os caboclos são considerados como mais maleáveis que os orixás e, por isso mesmo, seriam melhores protetores para os homens. Esses novos intercessores, emergindo ao lado dos santos católicos e das potentes divindades africanas, não gozam de estatuto tão prestigioso e se introduzem nas 
zonas sombrias onde os outros não penetram, não entrando portanto em concorrência direta com eles.

De certa forma, os santos católicos, na maioria "brancos", e os orixás, por sua vez "negros", vão encontrar-se reunidos em uma única e ampla categoria, a de caboclo, que integra, ainda, representações do índio e dos seus deuses. Mário de Andrade encontrou, na cidade de Natal, cantos dedicados à chamada dos "caboclos" Tupã, Manicoré e Xaramundí7. Enquanto categoria do sistema religioso, o caboclo dos cultos parece ter conseguido incorporar representações relativas a vários grupos da população.

Edison Carneiro foi o único da sua geração de pesquisadores a apontar para esse fenômeno. Em artigo publicado pela primeira vez em 1953, o autor mostra grande perspicácia quando sugere que, nos cultos, a categoria caboclo pode ser dividida em dois subgrupos. Encontrando um cântico em que a divisão parece implicitamente aceita, Carneiro dissocia os caboclos que têm "mirongas", ou segredos, os quais seriam uma representação do "índio de romance", dos caboclos que têm "dendê", os quais seriam "negros por baixo da roupagem do índio convencional" (1964: 145). Pode-se objetar que a divisão operada tem pouco valor heurístico, já que tanto "mironga" quanto "dendê" provêm de um fundo lingüístico africano. M as esta crítica reforça, na verdade, a associação inelutável entre índios e negros na categoria caboclo.

Em texto escrito em 1960, o mesmo autor precisa o seu pensamento no que tange aos caboclos de dendê, conhecidos também como caboclos de A ruanda (nome de um porto africano que se tornou nos cultos uma cidade mítica):

"Os caboclos de Aruanda devem muitos dos seus nomes e das suas virtudes ao indianismo, contraparte, nas letras, da revolução da Independência, mas a sua concepção data de muito antes de Alencar, como parte de uma tendência mais geral que, orientando-se para a valorização de padrões culturais africanos, resultou em novos modos e maneiras de integração do negro à nacionalidade brasileira" (1964:151).

Carneiro interpreta, portanto, a aparição desses caboclos negros em relação ao processo de integração do negro, este antigo africano que se tornou “um velho cidadão brasileiro" (1964:115). Desta perspectiva, a presença de caboclos negros nos cultos não traduz a simples desintegração dos costumes africanos; ela revela, sobretudo, a tentativa de atribuir ao negro - quando não dar a si mesmo enquanto sujeito negro - um 
espaço no universo simbólico em formação, análogo àquele que ocupam outros componentes da população.

É verdade que na umbanda do sul do país, as entidades representadas com pele negra foram reunidas em uma outra categoria, a de "pretos-velhos", reservando aos espíritos de índios a categoria de caboclo. No entanto, pode-se pensar que tal classificação expressa antes de tudo uma certa concepção da história, em que, entre outras coisas, o pretovelho lembra a nódoa da escravidão enquanto o caboclo encarna a condição de homem livre. $O$ exemplo dos cultos de Belém vai ao encontro das observações de Carneiro quando este afirma que os médiuns não fazem muita diferença entre os caboclos indígenas e os caboclos negros, pois os caboclos, que recebem suas características de fontes múltiplas, entrelaçando-as até torná-las inextricáveis, formam uma totalidade que não se divide em função de fenótipos ou de claras origens étnicas. Os médiuns dos cultos preferem classificá-los em função do seu pertencimento aos domínios da mata ou do mar e, dentro de cada um, em função de suas afinidades com subgrupos como "boiadeiros", "flecheiros", "marinheiros", "turcos"... Além disso, para os filhos-de-santo, caboclo nenhum ficaria preso a esse sistema de classificação. Na hora da possessão, qualquer médium competente - cuja reputação o autoriza a sustentar que sabe da vontade do seu caboclo - pode representá-lo quando um grupo diferente do dele está sendo chamado.

Deixando, por enquanto, a descrição do significado do caboclo invisível nos cultos de possessão e dos diversos aspectos que o personagem assume, devemos analisar a outra vertente semântica do termo, isto é, o caboclo enquanto designação de um tipo de população humana.

\section{A construção do significado de caboclo}

A etimologia habitualmente aceita para caboclo é aquela dada por Luís da Câmara Cascudo no seu Dicionário: “Caboco vem [do tupi] caá, mato, monte, selva, e boc, retirado, saído, provindo, oriundo" (1972:193). Françoise e Pierre Grenand (1990:27), com base nos escritos da segunda parte do século XVII, acrescentam que o termo foi primeiramente usado pelos índios Tupi da costa para designar os seus inimigos morando no interior, isto é, "no mato".

A pós uma definição inicialmente restrita ao índio, "selvagem" ou "manso", o termo caboclo passa também a qualificar o mestiço de índio com branco. Nesse sentido, caboclo remete ao termo tapuio, cuja defini- 
ção foi tão flutuante quanto a dele no que tange aos grupos que deviam ser assim chamados, bem como no que diz respeito ao seu suposto "grau de civilização". J osé Veríssimo concebia o Tapuio como "o filho legítimo da raça americana" (1970:13), enquanto Armando M endes o considerava como "o indígena, o cabôclo semi-civilizado, que vive entre a população sertaneja" (s/d:90) e Alfredo A. da M ata, como o "caboclo civilisado" $(1939: 304)^{8}$.

O processo, cada vez mais abrangente, levando à inclusão de novas populações nas definições de tapuio e de caboclo, aparece já na obra do Visconde de Beaurepaire. Tapuio é certamente o "nome genérico aplicado aos selvagens bravios no Brazil", mas, escreve o autor, "conservaram [também] essa denominação os aborigenes já mansos". A lém disso, o uso do termo estendeu-se "à generalidade dos mestiços, e neste caso corresponde ao termo Cabôclo" (1889:136). O significado atual de caboclo, constituído por volta de 1895 (Grenand e Grenand 1990:28), é assim o de habitante do interior, independentemente de sua origem: "hoje, escreve Câmara Cascudo nos anos 50, indica o mestiço e mesmo o popular, um caboclo da terra" (1972:192).

A través dos séculos, o sentido do termo caboclo carregou uma forte carga negativa para as populações que assim eram designadas. Câmara Cascudo lembra que, quando sinônimo oficial de índio, "foi vocábulo injurioso e El-Rei D. J osé de Portugal, pelo alvará de 4 de Abril de 1755, mandava expulsar das vilas os que chamassem aos filhos indígenas de caboclos" (1972:192).

No início do século XX, Vicente Chermont de M iranda mostra ainda clara desconfiança em relação ao caboclo:

“Caboclo, s.m. - Tapuio ou seu mestiço que já não se exprime no, completamente esquecido, nheengatu materno: ombreia com a degenerada e entorpecida raça conquistadora, calça lustrosas botinas, ostenta rutilantes gravatas, dança polcas e valsas, chega a ser coronel ou doutor, adquire maneiras cortesãs, mas sob a apatia atávica muito esconso, sopita o ódio de raça. OrguIhando-se de pertencer à estirpe tupi despreza soberanamente o africano e seus mestiços" (1988:12-13) ${ }^{9}$.

Mas esta definição, na qual brota uma notável aversão aos colonizadores portugueses, aplica-se melhor às elites do interior - empenhadas em seguir as modas das capitais longínquas e em encontrar elementos ideológicos Ihes assegurassem sua dominação - do que a seus modestos dependentes, pequenos agricultores e pescadores. A estes, que revela- 
riam de modo abrupto a natureza verdadeira dos nativos da região, isto é, sem o verniz de civilização apresentado pelas elites, conviria melhor a definição dada por M iranda (1988:86) do termo tapuio enquanto "caboclo rude e ignorante".

J á nos dicionários publicados a partir dos anos 30, não é raro constar uma definição de certa forma positiva de caboclo (mas não de Tapuio). Por exemplo, Raymundo M oraes, cujo objetivo declarado era estabelecer a "verdade" da Amazônia, assinala que o "termo é affectuoso, empregado com ternura. M eu Caboclo, Cabocla da gente" (1931:96). Alguns anos depois, Alfredo A. da Mata nota um outro "significado popular" da palavra, o caboclo como "homem distinguido" (1939:95). Essa mudança de tom para tratar do caboclo parece ter ocorrido também no Nordeste. F. A. Pereira da Costa, por exemplo, indica, em 1937, que se o vocábulo “out'ora tinha uma expressão depreciativa, injuriosa mesmo ao infeliz aborigene [...] constitue hoje, e vindo naturalmente já de longe, uma dicção familiar de affeto, intima, carinhosa mesmo: M eu caboclo; Caboclo velho" (1937:135). Acrescenta o autor que aplicado a mulheres, trata-se de um "tratamento intimo, affectivo [...], e em tom interjectivo, [serve] como expressão de admiração a de um porte elegante e de bello typo feicional: que cabocla bonita!" (1937:133; ênfases no original).

Esse novo registro de expressão não significa que tenham desaparecido as conotações pejorativas associadas ao termo. Em boa parte da literatura, "caboclo" permanece uma palavra injuriosa e negativamente definida. A lém do que, na realidade das relações sociais, o forte estigma associado ao termo caboclo faz com que as populações, ainda hoje, não aceitem ser caracterizadas dessa forma ${ }^{10}$. A multiplicação de significados refletiu, na verdade, a preocupação crescente dos intelectuais da A mazônia a respeito das potencialidades do caboclo homem.

\section{O caboclo bom da Amazônia}

$\mathrm{Na}$ época em que se diversifica a representação do caboclo, a Amazônia acorda de um sonho de prosperidade. No século anterior, a partir de 1840, a região experimentou um crescimento econômico impressionante baseado na extração da borracha ${ }^{11}$. Cidades como Belém e M anaus se beneficiaram da acumulação de riquezas: realizações arquiteturais grandiosas, salões literários e visitas de artistas europeus traduziam o desejo das elites de que a região pudesse rivalizar com o Rio de J aneiro ou Salvador. Mas a euforia foi de curta duração. A maioria dos investimentos favore- 
ceu a produção extrativista em detrimento da agricultura e da indústria, deixando a economia regional totalmente dependente das importações e sem condições de resistir, na década de 10, à queda dos preços resultante da concorrência inglesa na Ásia (Santos 1980). Portanto, nos primeiros decênios do século $X X$, a Amazônia já não podia mais pretender encarnar a modernidade e a "civilização", estas voltando a ser novamente associadas ao sul do país. Na verdade, a região voltou a apresentar

“[...] o mesmo panorama que um século mais cedo: multidão anônima, sem identidade aparente e a quem ninguém presta atenção; Índios bravos, obstáculo ao progresso, imagem que alimenta toda sorte de sonho; economia artificial de predação; natureza selvagem, ela também, magoada, espoliada, em nome da conquista da fronteira, este mito incessantemente recomeçado como um pesadelo paludífero" (Grenand e Grenand 1990:19).

Essa "multidão anônima" conta, no entanto, com novos acréscimos de população. Aos índios, descendentes de portugueses, escravos africanos ${ }^{12}$ e seus mestiços, juntaram-se a partir de 1860 imigrantes estrangeiros atraídos pela fama da Amazônia, dentre outros, europeus, sírio-libaneses e norte-americanos (Salles 1990:16). M as as grandes migrações, algumas induzidas pelo governo, outras espontâneas (Santos 1980:87), foram sobretudo inter-regionais. A seca de 1877 no Nordeste deu um novo impulso aos fluxos migratórios que vinham crescendo desde a década de 1810 e que contribuíram para a colonização de várias regiões da A mazônia, em particular no Estado do A cre (Santos 1980:98). Se uma parte dos nordestinos refluiu para outras regiões do país na década de 1910 (Santos 1980:263), outra parte ficou e teceu alianças, através do casamento e do compadrio, com os seus vizinhos instalados há mais tempo. Esses colonos 13 , o termo sendo usado para diferenciá-los dos grupos com ocupação mais remota, integraram-se progressivamente à população local, e receberam o rótulo de "caboclos" 14.

Devemos situar nesse contexto de relativa falência o debate, surgido na década de 20 entre as elitas nortistas, a respeito do caboclo. Com efeito, por trás das disputas afiadas, escondiam-se esperanças de um dia a A mazônia voltar a conhecer o esplendor perdido. Ora, as possibilidades de realização de tal projeto estavam intimamente ligadas, na mente desses intelectuais, às aptidões das populações que ocupavam o espaço regional. Era, portanto, urgente avaliar as características morais destas últimas, tal como a qualidade das suas produções materiais e simbólicas. 
Um tema recorrente nos trabalhos literários é a comparação entre os méritos dos "nativos" 15 da região - os caboclos - e aqueles dos migrantes do Nordeste - os cearenses. O estudo de J osé Carvalho, jornal ista e folclorista nascido no Ceará, é representativo dessa tendência16. $O$ autor, em um livro intitulado O M atuto Cearense e o Caboclo do Pará, considera que o primeiro é, "pela alma, ou pelas qualidades psychologicas, um sêr mais complexo, mais variado, mais multiforme" do que o segundo, descrito como "mais simples, mais primitivo, menos complicado" (1930:1). Desta perspectiva evolucionista, encontrando o seu ponto de partida no índio17, o paraense leva certa desvantagem em matéria de produção folclórica (as lendas, por exemplo). No entanto, logo a compensa por sua "índole" e seu "pendor" naturais, que não foram atingidos pela "civilização, [que] está [...] destruindo o Ceará, barbaro, mas poetico de outr'ora" (:122). O caboclo, natural de uma terra de pouca aflição e de grande abundância, mostraria uma "aptidão admirável para as artes e para a mecanica" (:6), e falaria o português "muito mais corretamente que o cearense" (:54). Deste novo bom selvagem, descrito como "manso", "calmo", de poucas "ambições e necessidades", "frio", "suspicaz", "discreto" e "religioso", J . Carval ho afirma: "É uma raça, pois, que poderá produzir grandes diplomatas [...] se a diplomacia fôr ainda uma coisa necessaria no futuro" (:3).

Um outro escritor, J orge Hurley (1934), formado em direito, que foi procurador-geral do estado e presidente do Instituto Histórico e Geográfico do Pará, discorda nitidamente desse retrato do homem amazônico, que acaba por enfatizar a falta de combatividade de um caboclo representado como acomodado e conformado com seu destino. No seu livro I tarãna, publicado em 1934, esse intelectual rejeita o que considera "phantasias prejudiciaes aos creditos da civilização do valle do A mazonas" (:5) e cita numerosos exemplos de notabilidades paraenses que contribuíram, ao longo do século XIX, para a grandeza nacional. Evoca o escritor e crítico literário J osé Veríssimo, "caboclo do Pará" e "saudoso mestre" (:19) nascido em Óbidos, e Enéas M artins, "caboclo cametauára [...] maneiroso, culto, erudito e intelligente" (:22) que assumiu as altas funções de diplomata e governador. Lembra também a "vocação militar dos caboclos amazonienses" através do "vulto do general Gurjão, morrendo heroicamente no Paraguay, na defesa da Patria e o paizano Veiga Cabral, o Cabralzinho, mais tarde general do A mapá, repellindo bravamente à frente de um grupo de paraenses, a invasão franceza do A mapá" (:23). Com menção do conservatório Carlos Gomes, de Belém, que "ha produzido musicos de incontestavel valor", termina ele insistindo na 
vocação musical do nativo, já que "no interior da Amazonia, quasi todo o caboclo é um musico espontaneo, improvisado" (:24). A explicação do sucesso de homens ilustres em domínios tão diversos quanto a política, o exército e a arte, encontra-se, para o paraense J orge Hurley, no temperamento amazônico. Habilidosos na arte de pintar, como na "mecânica" ou "na vida do mar", os amazonenses teriam igualmente disposição "para a medicina e para todas as conquistas do espirito" (:23).

N essa construção, exaltando as virtudes do "caráter" regional, a associação do caboclo com o mato ou o interior que povoa, e até com uma ascendência indígena, deixa de ser um obstáculo à sua glorificação. $\mathrm{A}$ proximidade com a "natureza" é, doravante, a fonte do seu gênio e das suas competências. É graças às qualidades intrínsecas à sua "raça" 18 que os homens da A mazônia podem ingressar na civilização, dando o melhor de si mesmos e levando-a à frente. Ao naturalismo do século XIX e ao pessimismo do início do século $X X$, sucede nas décadas de 20 e 30 uma visão otimista com autores preferindo "encontrar o paraíso que o inferno na Amazônia" (Preto-Rodas 1974:183)19.

O intuito, na elaboração de um caboclo bom e respeitável, é claramente de cunho ideológico: trata-se de fornecer às elites locais uma imagem gratificadora, suscetível de realçar o orgulho regional vis-à-vis a sociedade do sul do país, onde estão estabelecidos os centros de poder. Levando em conta os fins emancipadores dessa construção identitária, os esforços em volta da figura do caboclo apresentam uma certa analogia com a tentativa, no século passado, de fazer do índio o símbolo da coesão nacional e da independência brasileira perante o Império português.

\section{Um ponto problemático: a pajelança do caboclo}

Como em outras construções baseadas na oposição civilização/selvageria, as crenças e práticas religiosas do caboclo constituem um assunto problemático, e os estudiosos acabaram por desqualificá-las enquanto elementos resgatáveis. O cearense J osé Carval ho é o único a mostrar-se complacente em relação ao sistema religioso associado ao caboclo designado como "pajelança" - e ao seu especialista, o "pajé" 20. No entanto, a sua tolerância só vem à tona porque, para além da herança recebida do "índio selvagem", o autor acredita poder apontar, nas práticas da pajelança amazônica, para "esse contato tão flagrante com as praticas da antiguidade greca e romana" (1930:36). 
Como escreve A Idrin de Figueiredo em um trabalho recente, naquela época "a estratégia dos homens de letras foi decretar a morte da pajelança, por não reconhecer nas 'novas' práticas dos pajés de Belém, aquela religião 'primitiva' dos índios da Amazônia" (1996:216). Para eles, a arte dos pajés indígenas, que se considerava como uma espécie de medicina primitiva, transformou-se, com a sua passagem para o meio urbano, em pura feitiçaria (1996:237).

A definição de pajé dada por um desses estudiosos mostra, claramente, as bases espaciais e temporais que passam a sustentar o contraste entre a sabedoria atribuída ao especialista religioso indígena e o charlatanismo daquele que, na cidade, tem a pretensão de exercer o seu ofício. “Pagé- (Paié). Curandeiro, sacerdote, santo, mago da tribu; e, hoje, entre os crentes da magia negra, simples impostor da arte de curar e adivinhar" (Mendes s/d:70)21.

Práticas que eram toleráveis antigamente e em lugares recuados perdem, assim, a sua legitimidade no mundo moderno. Raymundo M oraes, defensor obstinado da imagem de um paraíso amazônico, foi um dos escritores mais prolixos sobre as feições passadas e presentes do pajé.

“De gesto enigmatico, olhar ameaçador, palavra sibilyna, contraditório, miseravel, sordido, o pagé é odiado e respeitado [na malocas indígenas]. Ridiculizam-n'o, desprezam-n'o e escutam-n'o" (1930: 225).

“O pagé é solene. Magro, vermelho, oleoso, nú, o seu trabalho de feiticeiro que é consultado como o eram os Grandes iniciados, desdobra-se com a gravidade sacerdotal, serena, confiante no proprio cordão de augure [...]. Mas o puro pagé aborigene, adstricto ao ritual vindo de longe, através de remotas gerações, projecta-se cruzado no pagé mameluco, no pagé mulato, no pagé curiboco, imaginoso, solerte, que se encontra nos povoados, nos villorios, nas cidades” (:229). Este, "muito desmoralizado já, bebaço, caloteiro, de fraque surrado, botas cambaias, chapeu sem abas, calças cerzidas, collete rasgado, camisa enxovalhada, corrente de relogio de cabellos trançados e cheia de figas, de favas, de dentes, de camafeus - ainda assim é procurado e consultado, não tanto talvez pelas doenças do corpo, sim pelas doenças da alma" $(: 230)^{22}$.

O retrato feito do pajé indígena é o de um personagem ridículo e afinal bastante patético. No entanto, pela sua fidelidade aos seus ancestrais, ainda conserva imponência e dignidade, gozando de prestígio entre os seus, como certas figuras primordiais, grotescas e poderosas das mitologias que assombram a literatura do século XIX ${ }^{23}$. Nada igual ao pajé da 
cidade. Sujo e bêbado, é apresentado como malandro, marginal, pobre e fetichista. A pajelança "degenerada" é então condenada a desaparecer com o progresso da civilização, e com ela o pajé urbano.

A imprensa, como documenta Aldrin de Figueiredo (1996, 2a parte), registra abundantemente os casos de pajelança, contribuindo para a cisão do pajé em duas imagens distintas: uma benéfica e inócua, a do "benzedor", e outra maligna, a do "feiticeiro". Esta divisão acabará nos anos 30 por levar definitivamente a pajelança para o lado da magia negra. A instituição judiciária, representante do "moderno" aparelho de Estado, também contribui para o processo de marginalização da pajelança quando, deparando-se com ela através das denúncias de "feitiçaria", a rejeita como obscurantismo do universo popular24. Ao que parece, os termos "pajé" e "pajelança" constituíram-se como categorias de acusação contra vizinhos ou parentes em momentos de atrito25, em um dispositivo eficaz já nos anos 20.

A o compararmos a representação do caboclo com aquela do pajé, tais como as encontramos na literatura do início do século, fica claro que o resultado do trabalho simbólico foi bem diferente nos dois casos. 0 caboclo foi visto por uma parte dos estudiosos como o produto valorizado da mestiçagem, um tipo de população que conseguiria facilmente acrescentar às qualidades do seu ancestral índio o conhecimento vindo da moderna civilização. $N$ essa construção, a responsabilidade pelo bom aproveitamento das capacidades da "raça amazônica" cabia aos homens políticos. Contrastando com isto, o personagem do pajé só adquire feições aceitáveis quando projetado longe do presente e da miscigenação, na maloca indígena. Quando situado o seu desempenho no mundo contemporâneo, aproveitar-se-ia do pior das crenças e superstições populares, favorecendo a permanência da ignorância (característica fundamental do povo segundo as elites), incompatível com o estado de civilização desejado. O caboclo bom tem futuro, o bom pajé já se foi. Tal formulação, subjacente ao pensamento dos defensores do caboclo, instituía, através da última asserção, um ponto de concórdia com seus mais ferozes adversários.

O projeto de constituição de uma identidade amazônica baseada na figura do caboclo ao qual as elites regionais pudessem aderir obviamente fracassou. Constituindo a maior parte da população atual da A mazônia, os caboclos "são uma categoria dominante do ponto de vista demográfico, [mas] sociologicamente subalterna" (Grenand e Grenand 1990:18) e ideologicamente negativa. No Brasil inteiro, quando se fala em caboclos, pensa-se em mestiços de índios, instalados na beira dos rios, 
vivendo da pesca e da colheita, de temperamento preguiçoso e desconfiado. Em outros termos, o caboclo, figura primitiva e exótica fora da Amazônia, representa dentro o "atraso" da região e das pessoas assim designadas, revelando às escondidas a exclusão do mercado de grande parte da população. O estigma carregado pelo estereótipo é tão forte que ninguém aceita reconhecer-se como caboclo. O termo vem então a ser usado para designar um “outro", cuja posição na estrutura social é supostamente inferior à do locutor. Deborah Lima, seguindo Charles Wagley, trata o "caboclo como categoria relacional" (1992:24). Os moradores da capital qualificam dessa forma os habitantes das cidades do interior, enquanto estes reservam o termo às pessoas do meio rural, e estas últimas aos índios.

\section{Voltando ao caboclo invisível}

As migrações de importantes contingentes populacionais entre o N orte e o N ordeste, prosseguindo às vezes para o sul do país, foram provavelmente essenciais para a consolidação, nas diversas regiões, da sinonímia entre cabocl o e nortista. Com efeito, considerando que o termo caboclo permite construir, ou melhor, expressar na linguagem cotidiana a diferenciação das posições sociais, e sabendo também que no Nordeste a palavra nunca foi um termo de autodenominação (Sigaud 1978:8), podese supor que nesta última região os migrantes vindos do N orte e apresentando no fenótipo traços de uma ascendência indígena, sejam rejeitados ao extremo, tornando-se os "caboclos" dos outros. N esse contexto, o termo caboclo constitui-se progressivamente em uma palavra operacional para enunciar qualquer diferença, podendo ser associada a uma origem geográfica nortista e, sobretudo, a uma diferença religiosa.

De fato, no Brasil, a originalidade das práticas religiosas vindas do Norte e o saber peculiar dos seus peritos eram referidos como caboclos. Já no início do século, era sem dúvida no domínio religioso que a reputação do caboclo se tinha firmado. Poder-se-iam dar exemplos de trabalhos literários, como o romance Esaú e J acó, de Machado de Assis, escrito em 190426, testemunhando a representação do caboclo primeiramente como especialista religioso. O amplo campo semântico coberto pelo termo permite evocar certas práticas cultuais, de modo implícito mas sem equívoco possível.

Convém aqui observar que os termos pajé e pajelança nunca foram de uso comum nos centros urbanos do país²7, a não ser, como foi mencio- 
nado acima, enquanto categoria de acusação, e assim mesmo na Amazônia, onde foram consagrados pela literatura clássica ao falar das práticas religiosas locais. Para a A mazônia, o antropólogo Heraldo M aués constata que hoje em dia em Vigia, na região do Salgado, "a pajelança não existe, para seus praticantes, como uma categoria explícita, no sentido de que [...] não existe um rótulo para ela" (1995:483). E para as primeiras décadas do século, o folclorista J osé Carvalho (1930:31) afirma que nem mesmo a palavra pajé era habitual, os consulentes falando com mais gosto de "curador".

Mas caboclo não era qualquer curandeiro ou feiticeiro. Atribuía-se a este especialista religioso a sabedoria de feitiços potentes e desconhecidos, porque oriundos de longe. Os homens a quem se chamava caboclos (isto é, os "pajés" oriundos das cidades da região amazônica e tidos por degenerados na literatura regionalista) gozavam de considerável fama e prestígio, que atraíam clientes e discípulos, o que fazia da sua região de procedência uma referência imprescindível. O folclorista Câmara Cascudo atesta essa reputação junto aos mestres do Catimbó no Estado do Rio Grande do Norte:

“Há no Catimbó muito Pará-A mazonas. São as universidades do curso secreto. A ordem, na citação respeitosa que é a credencial na ordem dos valores, começa por Belém do Pará, M anaus depois. Não se fal a bastante na Bahia. O terceiro lugar é Pernambuco [...]. Posso informar, em segrêdo para a Polícia não saber, que os mestres da Pajelança paraense, alguns de mais fama, são convidados a visitar capitais nordestinas para 'trabalhos' de importância [...]. Os Pajés vêm, trabal ham e deixam alguma técnica nas mãos dos mestres catimbózeiros locais [...]. Alguns mestres nordestinos juntam dinheiro e vão passar uns meses em Belém do Pará estudando, acompanhando um short course" (1951:79).

A Amazônia foi, dessa forma, um importante foco de circulação de homens e de saberes, os mestres do Catimbó deslocando-se para as cidades de Belém ou M anaus a fim de aprender novos mistérios dos nortistas caboclos e estes últimos respondendo a convites solicitando os seus talentos.

Em diversas regiões, ao uso pejorativo do termo na vida diária contrapunha-se um uso prestigioso na esfera religiosa, fazendo com que, ao ser conhecido como caboclo, um especialista religioso se beneficiasse a priori de uma reputação vantajosa. Reivindicar-se caboclo fazia parte do processo de consolidação de posições individuais no campo religioso 
local. Havia várias formas de ligar-se ao prestigioso universo caboclo: pelo lugar de nascimento, pela trajetória de migração e também pelos seres invisíveis representados durante as chamadas, a quem procuravam os consulentes.

Nesse sentido, a lógica religiosa - admitindo que com a morte os homens possam metamorfosear-se em espíritos - veio ao encontro das necessidades táticas determinadas pela demanda do mercado religioso. Com efeito, por analogia com o que acontecia aos seres humanos, caboclo era um atributo de alguns espíritos que nele se encarnavam. $O$ exemplo do Catimbó estudado por Câmara Cascudo ainda nos é precioso nesse ponto, ao informar que, desde a expulsão dos jesuítas no século XVIII, o termo era associado no Nordeste ao nome de alguns dos "mestres" falecidos quando se atribuía a eles uma ascendência indígena, da mesma forma que outros eram lembrados como "negro velho" quando tidos por descendentes de africanos. Ora, à medida que crescia o número de seres invisíveis caboclos junto com seu sucesso, aquilo que era qualidade pessoal de certos espíritos ou dos homens que os representavam, virou característica comum a todos.

A multiplicação dos espíritos de caboclos ameaçava diluir, dada a sua generalização, o significado da palavra, e, como conseqüência retrocessiva, limitava os efeitos de um uso diacrítico do termo entre os especialistas religiosos. Os estereótipos do índio "brabo e selvagem”, exótico e distante, vieram então nutrir o imaginário religioso, proporcionando uma caracterização mais estreita do que seria o caboclo autêntico. Os espíritos cabocl os foram revestidos do que era considerado genuinamente indígena: arco e flecha, saiote..., distanciando-se assim daqueles santos e orixás, também chamados caboclos, mas que não podiam receber igual tratamento. Uma definição cada vez mais restrita do indígena - do indígena sem existência real, é necessário insistir - contrabalançou, portanto, a tendência à inclusão de todo e qualquer ser invisível na categoria caboclo.

Com a Segunda Guerra M undial, e a perda das fontes asiáticas da borracha, a Amazônia recebeu, durante um curto mas decisivo período, novos contingentes nordestinos, que trouxeram para a região Norte suas “idéias religiosas" (Gabriel 1980:151), inclusive essa imagem particular do caboclo invisível. Mas a representação do caboclo como índio mal combinava com o uso local do termo e a sua dimensão "relacional". Devese também considerar o impacto das declarações dos intelectuais amazônicos a respeito da identidade regional, pois nos seus escritos, o caboclo era mais do que o índio. Não era somente uma figura associada à margi- 
nalidade e à selvageria; podia pretender pertencer às classes dominantes, entrar e contribuir com seu ideal de "modernidade". Dito de outra forma, o caboclo podia ser um senhor. Essa definição do ser caboclo pela essência, pela ênfase nas suas potencialidades e não pela aparência, abriu possibilidades infinitas de recomposição de uma figura bastante monolítica no N ordeste.

Encontramos evidências das repercussões, no âmbito religioso, do discurso dos intelectuais amazônicos e das lutas travadas para a afirmação de uma identidade regional. N os anos 60, em Belém do Pará, o termo caboclo intervinha em dois sistemas de classificação dos seres invisíveis: às vezes era um indicador da "família" - do grupo - à qual um espírito pertencia; outras vezes revelava o estatuto menor atribuído a ele, por oposição àquele dos senhores (Leacock e Leacock 1972:146)28. Esse deslize favoreceu a abertura do grupo dos caboclos a representações outras que a do índio ou do ribeirinho. Integraram-se a ele subgrupos evocando outros horizontes geográficos (tais como os turcos e os boiadeiros), que dificilmente representariam as populações locais nativas. À diferença de outras regiões do Brasil, na Amazônia, caboclo tornou-se uma categoria emblemática, reunindo todas as entidades poderosas.

Os caboclos invisíveis acabaram por ter representações antropomórficas, lembrando o seu passado de seres humanos. Em 1939, Câmara Cascudo (1951:45) fotografou as primeiras imagens de gesso pintado encontradas na cidade de Natal. A sua origem amazônica - as três foram compradas em Belém do Pará - e a diversidade dos fenótipos que inspiraram o artesão - uma das estátuas tem as feições de uma loura de pele branca - mostram que nessa região, como foi dito antes, o termo caboclo já tinha deixado de indicar somente uma ascendência indígena.

A ssim, temos de voltar à versão do caboclo trabalhada e aperfeiçoada pela literatura regionalista dos anos 30, para encontrarmos o elo entre esse representante do homem amazônico e o ser invisível dos cultos de possessão. Nos dois casos, houve uma tentativa análoga de apoderar-se de elementos simbolicamente associados à "margem", ao "atraso" e ao "incivilizado" para elaborar o "bom", o "forte", o "futuro". No entanto, a legitimação do caboclo pelas elites intelectuais passou pela rejeição de certos traços vistos como decididamente incompatíveis com a imagem que queriam dar (e dar-se) de si mesmos, isto é, a "pajelança supersticiosa". À diferença disso, a constituição da categoria emblemática dos caboclos foi levada a seu termo com mais sucesso nos cultos de possessão, em parte porque integrou todos os estigmas e estereótipos (inclusive a dimensão mágica do pajé) para reverter de uma forma ou de outra os seus 
significados 29 . A final, o caboclo foi separado da esfera religiosa pelos intelectuais para melhor incluir-se nela, agora enquanto categoria central do mundo invisível. Formou-se um conjunto único, cuja coesão não é necessariamente harmônica, onde podem expressar-se as diferenças sociais, culturais e geográficas. Desse ponto de vista, as inúmeras possibilidades de especulação oferecidas pela organização do mundo dos caboclos refletem as origens, os itinerários, as trajetórias e as condições diversas de uma população cuja maior característica é a mobilidade (Grenand e Grenand 1990:25) dos processos de sucessivas migrações.

Difícil pronunciar-se sobre as mudanças induzidas no imaginário amazônico por essa distorção do sentido inicial da palavra caboclo. Igualmente árduo avaliar as conseqüências para as populações qualificadas de caboclas em um contexto de forte entrosamento entre o campo e a cidade. Com certeza, a el aboração do caboclo enquanto tipo de população deu-se de forma complexa, através do olhar dos citadinos, buscando nos rurais elementos para a construção da sua própria identidade. A pesar de representar uma figura do campo, a representação do homem caboclo é um produto urbano, como o é por sua vez a construção do caboclo invisível. As populações amazônicas, a partir das quais se exercia esse trabalho simbólico, não tinham participação ativa nesses processos: recebiam o rótulo caboclo sem jamais ter condições de infletir o rumo do discurso do qual eram objeto, sem ter possibilidades de aceitá-lo ou contestá-lo. Para o meio urbano, pode-se pensar que a invenção do caboclo corresponde a uma tentativa de se livrar do "caboclismo", projetando em uma figura do mundo invisível qualidades que são defeitos, e até deficiências, na cidade. Resta analisar ulteriormente o seu significado no caso das populações rurais.

Para concluir, convém observar que a valorização do "negro" pôs fim à possibilidade de identificação das el ites nortistas com uma figura que nem mesmo conseguiu impor sua legitimidade na esfera do folclore. A influência da busca minuciosa de traços africanos fez-se sentir na A mazônia a partir da viagem a Belém de Mário de Andrade em 1927, e sobretudo após a chegada da M issão de Pesquisa Folclórica em 1938, encarregada de fazer o levantamento da contribuição do negro à cultura regional (Figueiredo 1996:251-261). A publicação do livro de Oneyda Alvarenga em 1950, cujo título Babassuê forneceu um nome doravante referido para as práticas religiosas que se supõe de origem africana, marca um momento importante na inflexão dos assuntos tratados pelos intelectuais da região. $O$ momento de glória do caboclo declinou, assim, à medida que se firmava o discurso sobre a "fidelidade à Á frica". Nessa meta de 
resgatar a "pureza africana" melhor conservada com o candomblé e os seus orixás, o destino do caboclo invisível, inclusive na Amazônia, foi de permitir firmar cortes no campo religioso, legitimando certas práticas religiosas e condenando outras.

Recebido em 13 de abril de 1998

A provado em 29 de junho de 1998

Véronique Boyer é doutora pela École des Hautes Études en Sciences Sociales em Antropologia Social e pesquisadora do CNRS (Centre National de la Recherche Scientifique, França). Desde 1996, participa de um projeto de cooperação entre o CNPq e o ORSTOM no Museu Goeldi de Belém. Publicou, além de artigos em revistas especializadas, o livro Femmes et Cultes de Possession au Brésil: les Compagnons Invisibles (1993). 


\section{Notas}

* Este tema já foi objeto de um artigo publicado nos Cahiers d'Études Africaines (Boyer 1992). Retomo aqui parte dele, e prossigo na análise a partir de novas leituras que me permitem tratar melhor da representação do caboclo, e de suas produções religiosas, nos trabalhos dos folcloristas nas três primeiras décadas do século. Agradeço a Deborah Lima suas observações a uma primeira versão deste texto, e a J orge Pozzobon e Ciro Campos pela paciência em corrigir meus erros de português.

1 É o termo usado pelos médiuns para designar os seres invisíveis que os possuem.

2 Com efeito, apesar de formarem categorias distintas, exus e caboclos são, em Belém, vinculados por uma relação de transformação. Assim, um caboclo poderia apresentar-se em um terreiro sob a forma de exu, quando deixa de encarnar um personagem familiar, inserido em um dispositivo de deveres e direitos, para representar uma força bruta capaz de realizar sem distinção os desejos de cada um. Para mais detalhes, ver Boyer (1993).

3 Os únicos a não ter correspondências com os caboclos são os orixás.

4 Os "encantados" são conhecidos em um culto do Norte do qual falarei a seguir: a pajelança amazônica. A pesar de apresentar-se sob uma forma animal, os encantados participariam de uma natureza humana (para o meio rural atual, ver Maués 1995). Escolhidos por outros encantados, esses seres humanos teriam sido transformados através do "encantamento", sem sofrerem decomposição da matéria corporal.

5 A apreciação da beleza das danças é evidentemente um fato subjetivo, e outros autores têm com certeza opiniões opostas àquela de Edison Carneiro. No entanto, o uso que este faz de termos diferentes para descrever as danças mostra a necessidade que ele sentiu de apontar claramente o estilo bem particular de cada uma.

6 Esta construção da relação do médium com o caboclo se baseia nas representações a respeito da complementaridade dos papéis socioeconômicos do homem e da mulher (produção e autoridade masculina, gestão e obediência feminina) no grupo doméstico. Quanto às mulheres, elas conseguem desapossar das suas atribuições o seu companheiro real ao impor as suas decisões em nome do caboclo que encarnam nas sessões dos terreiros, caboclo que é aqui claramente marcado por um signo masculino. Assim, elas encontram nas práticas rituais e na simbólica religiosa instrumentos para conquistar a sua autonomia em relação aos homens, sem romper com as normas e os valores da sociedade brasileira (ver Boyer 1993). 
7 Por exemplo, o autor anotou este canto consagrado ao caboclo M anicoré (Andrade 1963:81):

Eu sou aquele cabôco,

Sou o M estre dos Mestres,

Sou eu grande pagé!

Triunfei, Agicé!

O meu nome na aldeia

É do grande Mestre,

Do grande Manicoré!

Triunfei, Agicé!

8 Sobre o tapuio, vale ler o interessante ensaio de Carlos A raújo de M oreira N eto (1988). O autor analisa o processo de destribalização, através da formação dos redutos missionários, sofrido pelos grupos indígenas durante a história colonial, que transformou os "índios específicos", com as suas instituições sociais e cultura particulares, em "índios genéricos" (para usar da expressão de Darcy Ribeiro), "a ponto de não ser mais possível determinar - com base na língua e nas maneiras de viver de que participam - a matriz cultural de origem" (:81), isto é, a sua transformação em tapuios. Para Moreira N eto, as diferenças entre os tapuios e aqueles que chama "sertanejos amazônicos" (isto é, os caboclos que povoam o interior da região) são mais de natureza socioeconômica que cultural (:90). Com efeito, mesmo se o sertanejo "pode chegar a ter, em uma subcultura particular, uma porcentagem de elementos indígenas tão ou mais elevada que a freqüência de traços de forma particular (sempre compósita) de vida cultural do tapuio" (:82), ele é um membro da sociedade nacional, que encontra formas de ajustamento às novas condições de vida e integra-se individualmente ao mercado de trabalho, enquanto o outro não consegue viver fora do seu grupo de origem e tem o seu destino ligado ao futuro deste. Com a marginalização desse índio genérico, na segunda metade do século XIX, e o seu desaparecimento enquanto categoria social pertinente e economicamente identificável, o sertanejo amazônico ou caboclo torna-se portador "de uma cultura genérica" (:84).

9 Respeitei a grafia original das citações.

10 Ver, por exemplo, Faulhaber (1996:7) e Lima (1992:24).

11 Para uma análise detalhada dessa fase de expansão e do seu declínio, deve-se consultar o livro de Santos (1980).

12 O último carregamento de escravos provenientes da África ocorreu em 1834, havendo depois importação de outras províncias brasileiras até a véspera 
da lei Áurea. De modo geral, a presença negra na região amazônica parece ter sido bastante fraca, em torno de 7\% em 1890 (Salles 1971:51-52).

13 Os colonos, cuja maioria era oriunda do Ceará, eram também chamados cearenses, esse termo tornando-se o nome genérico de todos os nordestinos (Santos 1980:98).

14 Encontramos, por exemplo, no livro de J osé Carvalho a expressão “caboclo cearense" (1930:102).

15 Lima insiste com razão na dimensão histórica da "construção de quem é ‘nativo': o 'amazonense típico' da época é sempre definido em contraste com aqueles que são migrantes recentes e os grupos ameríndios, por um lado, e o grupo social identificado como branco, urbano e rico, por outro lado. O termo constitui uma 'categoria' intermediária no sistema de classificação social, situada entre categorias sociais opostas" (1992:37-38).

16 Outro exemplo analisado por Lima (1992:33-34) é o livro Os MongoMalaios e os Sertanejos, de Alfredo Ladislau publicado em 1923.

17 “No Ceará, o matuto ou sertanejo está, no tempo e na evolução da raça, mais longe da malóca ancestral do que o caboclo do Pará, ou da Amazônia" (Carvalho 1930:1).

$18 \mathrm{O}$ uso do termo raça não é aqui um epifenômeno, um simples legado do século XIX, condenado a desaparecer. Ainda hoje, podemos observar no discurso trivial, e às vezes também na produção erudita, processos análogos de substancialização e de reificação do social, por exemplo, quando a identificação de um grupo sociológico se faz a partir de características fenotípicas, no caso da "raça negra", ou quando são exaltadas as virtudes nacionais pela expressão "raça brasileira", escondendo as desigualdades sociais e as formas históricas de dominação.

19 No seu artigo, Preto-Rodas (1974) cita exemplos de outros autores amazônicos: Eneida de M oraes (Banho de Cheiro, republicado em 1989, pela Fundação Cultural Tancredo Neves, Coleção Lendo o Pará, no 2), Raymundo M oraes (Os Igaraúnas, 1938), A bguar Bastos (A A mazônia que Ninguém Conhece, 1932). Para uma análise do pensamento dos intelectuais amazônicos, das tendências e da evolução dos discursos, ver também o trabalho de Aldrin M oura de Figueiredo (1996).

20 Ver, por exemplo, a descrição seguinte do "mais celebre pagé do baixo Amazonas", uma mulher de nome Maria Brasilina: "Era uma mulher ignorante, analphabeta, mas que impressionava bem pelo seu porte e suas attitudes discretas, ponderadas, intelligentes. Tinha o porte de uma verdadeira matrona. Não se gabava de sua 'sciencia'; não se envaidecia com sua popularidade. Era modesta, discreta e caridosa. Era casada e tinha filhas moças" (Carvalho 1930:33-34). 
21 Ver, também, Osvaldo Orico: “Encontram-se, ainda hoje, em Belém e $M$ anaus, tipos curiosos, que se propõem a exercer entre gente civilizada o mesmo papel reservado nas malocas ao paié dos indigenas" (1975:232).

22 Hurley (1934:138), em uma descrição de uma festa junina em Curuçá, menciona como personagem do enredo a figura de um pajé, igualmente representado como bêbado, grosseiro e sujo.

$23 \mathrm{Um}$ bom exemplo desse pano de fundo fantasmagórico para o fim do sécuIo XIX é fornecido por Figueiredo (1996) na sua análise dos escritos do jornalista Pádua Carvalho. O historiador identifica uma produção estética e literária que exalta a figura do pajé "primitivo", ao lado da sua contribuição propriamente jornalística, em que as ocorrências policiais servem de base para uma estigmatização da pajelança urbana.

24 Para o Rio de J aneiro, M aggie (1988) analisa com fineza como "os mecanismos reguladores criados pelo Estado a partir da República [...] foram fundamentais para a constituição" da crença na feitiçaria (:5). Pronunciando-se sobre os casos que Ihe eram submetidos, a J ustiça chegou a uma classificação e a uma hierarquização das diversas posi ções estéticas e filosóficas (:273) no campo religioso da possessão.

25 Encontram-se assim, no Arquivo Público de Belém, os autos de um processo, datado de 1921, que foi aberto para tratar de uma denúncia de aborto. A pesar do amante da acusada ser qualificado de "celebre Pajé Albertino" na carta mandada pela sua irmã às autoridades, a fama não significa neste caso competência, pois a denunciante afirma que foi preciso recorrer a uma parteira italiana para conseguir expulsar o feto. A acusada negou conhecer Albertino e os médicos não puderam determinar se houve "provocação do aborto" ...

26 Por exemplo, na primeira cena do livro, quando uma socialite vai à casa de uma cabocla, em um morro do Rio de J aneiro, não se espera desta última outra coisa que revelações sobre o destino, o que ela precisamente faz vendo o futuro dos filhos da senhora.

27 Ver, por exemplo, sobre Manaus, Gabriel (1980:89).

28 O exemplo dado por Gabriel (1980:195), de um espírito caboclo do qual os médiuns dizem que se formou e é hoje "educado" , atesta essa nova avaliação das capacidades do caboclo.

29 Dessa perspectiva, analisei, em um artigo publicado nos Archives de Sciences Sociales des Religions em 1992, como atualmente os médiuns constroem o personagem do caboclo a partir dos traços de comportamentos desvalorizados pelas classes médias, e associados por elas ao povo freqüentador dos terreiros (Boyer Araujo 1992). 


\section{Referências bibliográficas}

ANDRADE, Mário de. 1963. Música de Feitiçaria no Brasil. São Paulo: Livraria Martins Editora.

BEAUREPAIRE, Visconde. 1889. Dicionarios de Vocabulos Brazileiros. Rio de J aneiro: Imprensa N acional.

BOYER, Véronique. 1992. “De la Campagne à la Ville: La Migration du Caboclo". Cahiers d'Études Africaines, XXXII(125):109-127.

.1993. Femmes et Cultes de Possession au Brésil: Les Compagnons Invisibles. Paris: Éditions L'H armattan.

BOYER ARAUJ O, Véronique. 1992. “De I'A ppartenance Populaire à l'Affirmation de sa $M$ édiumnité (BelémBrésil). From Popular Origins to the Affirmation of One's Power as a Medium". Archives de Sciences Sociales des Religions, 79:101-114.

CÂMARA CASCUDO, Luís da. 1951. Meleagro. Rio de J aneiro: Livraria Agir Editora.

1972 [1954]. Dicionário do Folclore Brasileiro. Instituto Nacional do Livro/M inistério da Educação e Cultura.

CARNEIRO, Edison. 1961 [1948]. Candomblés da Bahia. Ed. de Ouro. . 1964 [1953]. Ladinos e Crioulos. Rio de J aneiro: Ed. Civilização Brasileira.

CARVALHO, J osé. 1930. O Matuto Cearense e o Caboclo do Pará. Belém: Officinas Graphicas/J ornal de Belém.

FAULHABER, Priscila. 1996. Identificação de Populações, Indianidade e Ambientalismo: As Redes Sociais em Tefé. Relatório de Pesquisa apresentado ao CNPq, Museu Goeldi, Belém.
FIGUEIREDO, Aldrin M oura de. 1996. A Cidade dos Encantados: Pajelanças, Feitiçarias e Religiões Afro-Brasileiras na Amazônia (A Constituição de um Campo de Estudo 1970-1950). Dissertação de M estrado, Unicamp.

GABRIEL, Chester E. 1980. Communications of the Spirits: Umbanda Regional Cults in Manaus and the Dynamics of Mediumnistic Trance. Thèse de Doctorat, Mc Gill University.

GRENAND, Françoise e GRENAND, Pierre. 1990. “L'Identité Insaisissable: Les Caboclos Amazoniens". Études Rurales, 120:17-39.

HERSKOVITS, M elville. 1966. The N egro and the New World. Bloomington: Indiana University Press.

HURLEY, J orge. 1934. “Itarãna: Lendas, M ythos, Itarãnas é 'Folk-Lore' A mazonicos". Belém, Separata do vol. IX da Revista do Instituto Histórico e Geográfico do Pará.

LEACOCK, Seth e LEACOCK, Ruth. 1972. Spirit of the Deep. New York: Anchor Books.

LIMA, Deborah de Magalhães. 1992. The Social Category Caboclo: History, Social Organization, Identity and Outsider's Social Classification of an Amazonian Region (The Middle Solimões). Ph.D. Thesis, Cambridge University.

MAGGIE, Yvonne. 1988. O Medo do Feitiço: Relações entre Magia e Poder no Brasil. Tese de Doutorado, PPGAS/M useu Nacional.

MATA, Alfredo Augusto da. 1939. Contribuição ao Estudo do Vocabulario Amazonense.

MAUÉS, Heraldo. 1995. Padres, Pajés, Santos e Festas: Catolicismo Popu- 
Iar e Controle Eclesiástico. Belém: Cejup.

MENDES, Armando. s/d. Vocabulario Amazônico Relacionado com Expressões Usuais.

MIRANDA, Vicente Chermont de. 1988 [1905]. Glossário Paraense. Belém: Universidade Federal do Pará.

MORAES, Raymundo. 1930. Paiz das Pedras Verdes. M anaus: Impresa Publica.

. 1931. O Meu Diccionario de Cousas da Amazonia. Rio de J aneiro: Moreira, Cardoso e Coelho.

MOREIRA NETO, Carlos Araújo de. 1988. Índios da A mazônia, da M aioria a Minoria (1750-1850). Petrópolis, RJ : Vozes.

ORICO, Osvaldo. 1975 [1937]. Mitos Ameríndios e Crendices A mazônicas. Brasília: Civilização Brasileira.

PEREIRA DA COSTA, F. A. 1937. Vocabulário Pernambucano. Recife, Separata do vol. XXXV da Revista do Instituto Archeológico Histórico e Geográphico Pernambucano.

PRETO-RODAS, Richard. 1974. “Amazonia in Literature: Themes and Changing Perspectives". In: C. Wagley (ed.), Man in the Amazon. Gainesville: The University Press of Florida. pp. 181-198.

QUERINO, Manuel. 1955. A Raça Africana e seus Costumes. Salvador: Livraria Progresso Editora.

RAM OS, Arthur. 1951 [1934]. O Negro Brasileiro. São Paulo: Companhia Editora Nacional (col. Brasiliana). . 1956. O Negro na Civilização Brasileira. Rio de J aneiro: Livraria-Editora da Casa do Estudante do Brasil. RIBEIRO, René. 1978 [1952]. Cultos AfroBrasileiros do Recife. Recife: MEC-
Instituto J oaquim Nabuco de Pesquisas Sociais.

RODRIGUES, Nina. 1977. Os Africanos no Brasil. São Paulo: Companhia Editora Nacional.

SALLES, Vicente. 1971. O Negro no Pará sob o Regime da Escravidão. Rio de J aneiro: Fundação Getulio Vargas. .1990. O Negro e as Transformações Sociais no Fim do Século XIX no Grão-Pará. Belém: Edição do Autor.

SANTOS, Roberto. 1980. História Econômica da Amazônia: 1800-1920. São Paulo: T. A. Queiroz.

SIGAUD, Lygia. 1978. “A Morte do Caboclo: Um Exercício sobre Sistemas Classificatórios". Boletim do Museu Nacional, 30 (N ova Série).

VERÍSSIM O, J osé. 1970 [1878]. Estudos A mazônicos. Belém: Universidade Federal do Pará 


\section{Resumo}

O personagem do caboclo, representado pelos médiuns durante a possessão, é uma figura central dos cultos de possessão da A mazônia urbana. O termo designa também, de modo pejorativo, as populações ribeirinhas da região. Neste artigo, procuramos entender a relação entre o caboclo invisível e poderoso dos cultos e o caboclo-homem visto como atrasado. A pós situar o processo de formação dessa categoria do mundo invisível, e sua especificidade, voltamo-nos, com base na literatura folclórica, para a construção de seu significado enquanto designação de um tipo de população regional. Observamos que os intelectuais amazônicos, suavizando as conotações negativas do termo, tentaram fundamentar nele uma construção identitária original. Esta valorização do caboclo-homem veio ao encontro do prestígio do migrante nortista no domínio religioso. Tal fenômeno favoreceu a multiplicação de referências a entidades invisíveis designadas como caboclo. No entanto, ao contrário do que ocorreu no resto do Brasil onde essa categoria se restringiu a um estereótipo do índio, na Amazônia ela se abriu aos mais diversos tipos de população, permitindo a sua identificação com ela.

\section{Abstract}

The persona of the caboclo or 'mestizo,' represented by mediums during possession, is a central figure in the possession cults of urban A mazonia. Yet the term is also used pejoratively to designate the region's riverine populations. This article aims at understanding the relationship between the invisible and powerful caboclo found in the cults, and the human caboclo perceived as backward. After establishing the specific way in which this category of the invisible world takes shape, the paper turns to folk loric literature and examines the evolution of caboclo's meaning as a designation for a type of regional population. We find that Amazonian intellectuals, softening the term's negative connotations, attempted to use it as the basis for an authentic regional identity. This valorization of the human caboclo combined with the religious prestige of the Northern migrant, a phenomenon which in effect stimulated an increase in the number of allusions to invisible entities designated by the term. However, in contrast to the rest of Brazil where the category caboclo was restricted to a stereotype of the Indian, in A mazonia the category opened itself to a wide range of populations, allowing their identification with it. 